\title{
THE GOOD AND THE JUST IN ROMANS 5:71
}

\author{
Andrew D. Clarke
}

In Romans 5:6-8 Paul contrasts the greatest acts of human heroism on behalf of a good or righteous man with the far greater act of self-sacrifice which was made by Jesus Christ on behalf of us sinners. The thrust of Paul's argument highlights God's action in his Son. So clear is this thrust that a number of commentators have tended to skip over the possible difficulties of verse 7 , to concentrate on the impact of verses 6 and $8 .^{2}$

In fact, the argument of verse 7 has appeared to many somewhat incongruous, and has led interpreters to adopt a number of quite different stances. The verse can be divided into two clauses-7a, 'for scarcely will anyone die for a 8ikaıs; and $7 \mathrm{~b}$, 'though for $\delta$ a yatós someone might possibly dare to die'.

\section{Romans 5:7 in recent interpretation}

The main problem in this verse has been determining whether a contrast is being drawn between $\delta$ k kaios and $\delta$ dyatoss, or whether, in essence, these two nouns are synonymous. There are six principal lines of interpretation commonly adopted.

The majority of commentators argue that the nouns are essentially synonymous, with some arguing for complete identity between the two types of people. ${ }^{3}$ Thus verse $7 \mathrm{~b}$ simply

\footnotetext{
${ }^{1}$ References throughout giving only author and page number will be to the person's commentary on Romans.

${ }^{2}$ Y. Landau, Martyrdom in Paul's Religious Ethics: An Exegetical Commentary on Romans 5:7', Immanuel 15 (1982-83) 25, points out that since the intended comparison in vv. $6-8$ is clear, the exegetical difficulties of v. 7 are often overlooked. W.G. Kümmel, Exegetical Method: A Student Handbook (ET; New York, Seabury Press 1981) 63, suggests that no real certainty regarding the meaning of 5:7, despite it being the crux interpretatum, can be attained; F.F. Bruce, The Letter of Paul to the Romans (Leicester, IVP 1985) 117, offers little discussion of the clause concerning Slkalos. C.K. Barrett, The Epistle to the Romans (London, A. \& C. Black 1984) 106, suggests that the details of v. 7 are insignificant, and moves quickly on to v. 8 .

${ }^{3}$ Amongst these are some of the older commentators, including Calvin. More recently H.A.W. Meyer, Critical and Exegetical Handbook to the Epistle to the Romans (ET; Edinburgh, T. \& T. Clark 1879) 232; Bruce, 117, who suggests that
} 
allows for the outside possibility that such a sacrificial act of heroism might just happen. In this sense, we may paraphrase Paul: 'Rarely will anyone die for a just or good man, although someone may possibly do it.'

A modification of this view suggests a distinction in meaning between $\delta$ k kalos and $\delta$ dyados. The latter is a stronger description. A 'just' man would describe the person who, before the letter of the law, is unimpeachable. Although such a person may well be admirable, he is somewhat without compassion. It is the person who is 'good' that attracts more sentiment. One who is dyatos is prepared to go beyond the call of duty, and is, therefore, a more compelling cause for heroism. ${ }^{4}$ Paul makes a valid point at the outset, and modifies it later with a slight concession. In this sense, he might be saying: No one is really prepared to die for the man who is merely lawabiding; although it does occasionally happen that a man might lay down his life for the kind and generous friend.' One clear argument for this stance has been put forward by Landau who suggests that the

pre-Christian ideal of righteousness, especially proclaimed by the Pharisaic opponents of Paul's embryonic religion, is rejected by the apostle along with any attachment to the outmoded Law which dispensed death. Any man who claimed to be righteous according to the old, Judaic standard was, in Paul's post-conversion view, a deluded moralist at best, and a hypocritical legalist at worst. This unflattering image would not evoke great sympathy, much less heroic altruism, on

there is really very little distinction in this passage between the two qualities; and J. Murray, The Epistle to the Romans I (Grand Rapids, Eerdmans 1959) 1678, who goes so far as to argue that the same person is being characterized here as possessing the qualities of both justice and goodness.

${ }^{4}$ Cf. C.H. Dodd, The Epistle of Paul to the Romans (London, Hodder and Stoughton 1947) 75; L. Morris, The Epistle to the Romans (Leicester, IVP 1988) 223-4; F.J. Leenhardt, L'Épitre de Saint Paul aux Romains (Geneva, Labor et Fides 1981) 79 n.5; W. Sanday and A.C. Headlam, A Critical and Exegetical Commentary on the Epistle to the Romans (Edinburgh, T. \& T. Clark 1920) 128; J.B. Lightfoot, Notes on Epistles of St Paul from unpublished commentaries (London, MacMillan and Co. 1904) 287; E.H. Gifford, The Epistle of St. Paul to the Romans (London, John Murray 1886) 113; J.A. Ziesler, The Meaning of Righteousness in Paul: $A$ linguistic and theological enquiry (Cambridge, CUP 1972) 197; and H. Cremer, Biblico-Theological Lexicon of New Testament Greek (ET; Edinburgh, T. \& T. Clark 1883) 3. 
the part of another who might be in a position to sacrifice his life for this dikaios. 5

A third position, which is also common, is to suggest that Paul, having made the statement in verse $7 a$, immediately realises that it is both rash and untrue. His reaction is to withdraw it hastily, although somewhat clumsily, with a correction in the second part of the verse. ${ }^{6} \mathrm{On}$ this reading, no particular distinction in meaning between $\delta$ Kcalos and dyatós is supported. Quite simply, Paul has made a considerable overstatement, which he immediately retracts.

A fourth possible interpretation relies on the suggestion that the article preceding dyatos provides a deliberate

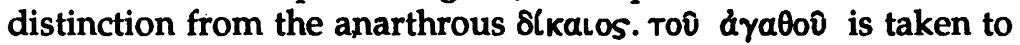
be neuter-'the good cause' - where slkalos is still understood as a masculine noun, 'a just man'. In this case, it is argued that it is extremely rare that anyone might die simply on behalf of another fellow human-being, but it is more common to witness someone consumed by a good cause to such an extent that he is prepared to lay down his life for it. ${ }^{7}$

${ }^{5}$ Landau, op. cit. 31. Agathos is contrastingly seen as a 'more human, generally attainable and respectable virtue than the more lofty and suspect ideal of "Judaic" righteousness.' idem 33.

${ }^{6}$ Cf. F.J. Leenhardt, The Epistle to the Romans (ET; London, Lutterworth Press 1961) 136; D.H. Lietzmann, Einführung in die Textgeschichte der Paulusbriefe an die Römer (Tübingen, J.C.B. Mohr 1983) 59; M.-J. Lagrange, Saint Paul Étitre aux Romains (Paris, 1950) 103; H. Schlier, Der Rómerbrief (Freiburg, Basel, Wien, Herder 1977) 153; O. Kuss, Der Romerbrief (Regensburg, Verlag Friedrich Pustet 1963); U. Wilckens, Der Brief an die Römer I (Zürich, Benziger Verlag 1978). E. Käsemann, Commentary on Romans (ET; Grand Rapids, Eerdmans 1980) 137 , comments on $v$. $7 b$, 'the apostle remembers that sacrificial deaths are common enough. He thus concedes quite tortuously this possibility as regards the good'; and Barrett, 105, offers the possibility that Paul intended to retract his initial, inappropriate comment and replace it with the second clause. His amanuensis, Tertius (Rom. 16:22), however, failed to delete the first statement, and thus it remains. A modification of this general stance is taken by G. Bornkamm, 'Paulinische Anakoluthe im Römerbrief', Das Ende des Gesetzes (München, Chr. Kaiser 1966) 78, where 5:6-8 is taken to be 'einen mühsamen Versuch des Paulus, der Sprache die zutreffende Formulierung seines Gedankens abzuzwingen.'

7 A major exponent of this view is F. Godet, Commentary on St. Paul's Epistle to the Romans I (Edinburgh, T. \& T. Clark 1895) 327. The neuter is firmly denied by many commentators including Lagrange, 103; R.C.H. Lenski, The Interpretation of St. Paul's Epistle to the Romans (Columbus, Lutheran Book Concern 1936) 351; and Käsemann, 137. The principal objection to this reading is 
A fifth line of interpretation, but recently much less common, must be mentioned. Cranfield, maintaining that tov

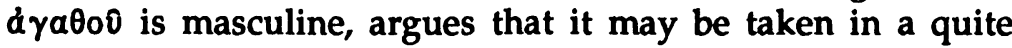
different sense from the general 'a good man'. It deliberately refers to a more specific 'the good man', namely one's benefactor. After a discussion of other possible interpretations, Cranfield finally offers this solution, but it is neither expanded nor substantiated in much detail. ${ }^{8}$

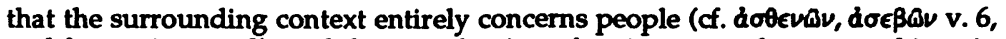
and duaptwhav v. 8), and the introduction of an impersonal cause at this point is unnatural, cf. F. Wisse, The Righteous Man and the Good Man in Romans V.7', NTS 19 (1972-3) 92. C.E.B. Cranfield, A Critical and Exegetical Commentary on the Epistle of Paul to the Romans I (Edinburgh, T. \& T. Clark 1979) 264, argues that if the neuter is intended in the second clause, then it is a serious understatement, bearing in mind the considerable numbers who had died in battle for their country. C.F.D. Moule, An Idiom Book of New Testament Greek (Cambridge, CUP 1959) 111, argues that the article is not demonstrative but deictic (pointing to some familiar type or genus); cf. also A.T.A. Robertson, Grammar of the Greek New Testament in the Light of Historical Research (Nashville, Broadman 1923) 763, a generic article.

${ }^{8}$ A similar suggestion was made by F.A.G. Tholuck, Exposition of St. Paul's epistle to the Romans I (Edinburgh, 1833) 262, Perhaps also the article before ayaobs is here significant, and stands for the pronoun, quasi, his benefactor.' (This interpretation of the use of the article is commonly adopted by those who see dyatoss as a reference to one's benefactor.) See also O. Michel, Der Brief an die Römer (Göttingen, Vandenhoeck \& Ruprecht 1978) 182. J.A. Ziesler, Paul's Letter to the Romans (London, SCM 1989) 140-1, hesitates between the two possibilities of 'the good cause' (neuter), or 'the benefactor' (masculine). Cranfield is followed by B.W. Winter, 'The Public Honouring of Christian Benefactors, Romans 13:3-4 and 1 Peter 2:14-15', JSNT 34 (1988) 93. Quoted by a number of commentators (including Cranfield, 265, Michel, 181 n.20, and J.D.G. Dunn, Romans 1-8 (Dallas, Word Books 1988) 256), is the papyrological excerpt brought to light by A. Deissmann, Light from the Ancient East (ET; London, Hodder 1927) 118, Herculaneum Vita Philonidis 1044, '[For] (?) the most beloved of his relatives or friends he would readily stake his neck.' It is interesting to note that this interpretation of the dyabos as one's benefactor received much greater support in the last century and earlier part of this century. Further commentators adopting a similar stance who have not been widely referred to should be brought to light at this point. D.J.G. Rosenmüller, Scholia in Novum Testamentum III (Norimberg, 1829) 605, suggests that 8lkalos here carries the sense of bonus, and dradbs carries the sense of vir beneficus. His paraphrase of 5:7b is, Pro viro benefico (qui magnis nos ornavit beneficiis) forsitan quis animum induxerit oppetere mortem. F.A. Philippi, Commentary on St Paul's Epistle to the Romans (ET; Edinburgh, T. \& T. Clark 1878) 240-243, who has a careful discussion of the classical usage of dra06s and 8lkatos, from which is drawn the conclusion that there is some gradation in sense between the two terms, Philippi suggests, 'Thus, doubtless, $\delta$ dyaobs comes very near to the

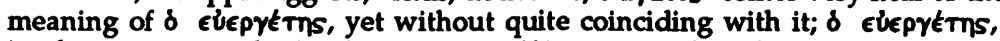
implying more another's relation to myself in respect of conduct; $\delta$ draobs, more 
Finally, there is the group of commentators who solve the anomalies by suggesting textual emendations, variations or glosses. ${ }^{9}$

There are thus six principal interpretations of the

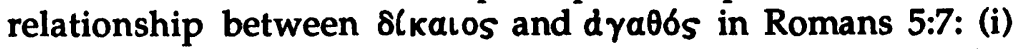

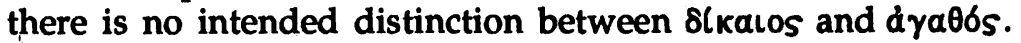
Rare occurrences of personal self-sacrifice on behalf of the good

a description of another's character in itself.' Meyer, 232-235, although disagreeing with the association with the benefactor, offers a long list of commentators who do adopt this position. In a later edition of the Meyer series, B. Weiß, Kritisch exegetisches Handbuch uber den Brief des Paulus an die Römer (Göttingen, Vandenhoeck and Ruprecht 1886) 248, the possibility of the benefactor is not ruled out of account entirely. P.C. Boylan, St. Paul's Epistle to the Romans (Dublin, M.H. Gill 1934) 79, 'As the context speaks of persons rather than of things, it is better to take $\delta$ ikalov and dya 000 as masculines-

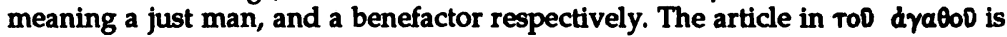
practically equivalent to "his". One will scarcely die for a just man, though, possibly, a man may decide to die for his benefactor.' Also A. Nygren, Commentary on Romans (ET; London, SCM 1952) 200f., Paul does not deny that human love may lead one to die for another. But it would require a strong motivation. ... One would be most likely to make the sacrifice for a relative or a benefactor. But for whom did Christ lay down his life? Not for benefactors, but for enemies; not for the righteous, but for sinners and the ungodly. This is truly "unmotivated" love.'

${ }^{9}$ Cf. L.E. Keck, The Post-Pauline Interpretation of Jesus' Death in Rom 5,6-7, in C. Andresen and G. Klein ed., Theologica Crucis-Signum Crucis, Festschrift für Erich Dinkler (Tübingen, J.C.B. Mohr [Paul Siebeck] 1979) 237-248, who argues that the cumulative evidence of the text-critical problems of 5:6; the apparent redundance of vv. 6-7 if retracted from the paragraph; and the repetition of the content of v. 6 in v. 8 suggest that we are dealing here with a post-Pauline addition to the text. $\mathrm{H}$. Sahlin, 'Einige Textemendationen zum Römerbrief, Theologische Zeitschrift 9 (1953) 96f., argues that there is the fumbled correction of a copyist's mistake; v. 7 is a secondary addition containing two apparently contradictory glosses. Cf. also Fuchs, Freiheit 15-16, W. Schmithals, Der Römerbrief, Ein Kommentar (Gütersloh, G. Mohn 1988) 198-9, and A. Jülicher, Der Brief an die Römer II (Göttingen, 1917), who are cited and refuted by Käsemann and Dunn. Jülicher's argument that the gloss was added in order to take account of Christian martyrs is adopted by J.C. O'Neill, Paul's Letter to the Romans (Harmondsworth, Penguin 1975) 94. We may also note here the lack of textual support for v. 7 amongst some of the Fathers. J.S. Semler, Paraphrasis epistolae ad Romanos (Magdeburg, C.H. Hemmerde 1769) 57, Wilckens, 295 n.975, and Dunn, 245 notice the omission of the verse in Irenaeus. Semler concludes this to be suggestive that the verse was not originally Pauline; but it may simply be that only 5:6, 8-10 served the writer's purpose. Marcion also appears not to refer to this verse, although it would seem that it might suit his thesis of the good and the just Gods admirably, cf. A. von Harnack, Marcion: Das Evangelium vom fremden Gott (Leipzig, 1924) 105. The possible gnostic link was pointed out by Sanday and Headlam, 128, and A. Pallis, To the Romans (Liverpool, OUP 1920) 77. 
and righteous man are possible; (ii) $a \gamma a \theta b s$ is a stronger term than $\delta$ lkalos, and it depicts a warmer and more genial character than the merely law-abiding citizen; (iii) the two terms are virtually synonymous; Paul has overstated his case,

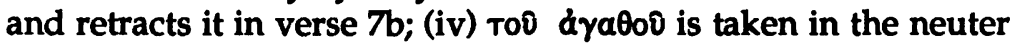
sense of a 'good cause' - a more compelling ground for selfsacrifice than to die on behalf of a fellow human-being; $(v)$ Tov a ya $\theta 00$ is taken in the technical sense of a patron or benefactor to whom one has greater obligations; and (vi) The text of Romans 5:7 is in some way not original.

To clarify the relationship between the two nouns, we need to ask a number of questions. Godet has perceptively articulated these. Why does Paul substitute $\delta$ dyatos for $\delta$ l kalos in the second half of the verse? Why is there a distinction between the two nouns in the presence or absence of

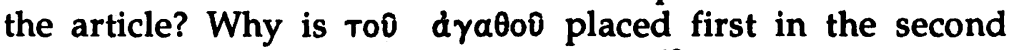
clause, thus creating a marked contrast? ${ }^{10}$ Why does Paul use Kal in verse $7 \mathrm{~b}$, implying some gradation? ${ }^{11}$

From a syntactical point of view, these are objections to the interpretation that the nouns are approximately synonymous. We may also note a number of commentators who affirm a distinction in meaning in Greek literature between ¿yatós and sikacos. ${ }^{12}$

It is almost universally accepted that Paul is using a secular analogy in Romans 5:7.13 For this reason, it is to the normal secular usage of the two nouns that we should turn for discussion of the meaning of these descriptions. ${ }^{14}$

\footnotetext{
${ }^{10} \mathrm{Cf}$. also Tholuck, 258.

${ }^{11}$ Godet, 325.

${ }^{12} \mathrm{Cf}$. Tholuck, 258; Lightfoot, 286-7; and Gifford, 123.

${ }^{13}$ We may contrast Paul's 'theological' use of $d y a 06 s$ in Romans 7:18-19. In Romans 5:7, he is simply talking of what is commonly recognised in GrecoRoman society as good.

${ }^{14}$ Cf. E. Käsemann, Perspectives on Paul (ET; London, SCM 1971) 45. Dunn, 256, follows Wilckens in pointing out that Paul does not use dratos in this sense anywhere else. For further discussion of Paul's use of analogy see H.M. Gale, The Use of Analogy in the Letters of Paul (Philadelphia, The Westminster Press 1964) esp. 175-7, 223-31.
} 


\section{II. dya日bs and 8lkalos in Classical and Hellenistic Greek}

Although it may be noted that these two nouns are normally thought of as qualities which go together to describe a person, often a ruler, this merely shows that the two qualities are commended and not necessarily incompatible. ${ }^{15}$ Liddell and Scott shows that $\&$ kalos is understood as observant of custom or rule, and of duty to the gods. In many contexts, dyaObs is seen more as a comment on social standing. The first meaning given is that of well-born, and the fourth meaning is closer to our idea of 'good' in its moral sense.

In a study of traditional Greek values, Adkins demonstrates the development of the word dyatoss. ${ }^{16}$ It was amongst the most valued words of praise that could be attributed to a man in Greek society from Homeric days onwards. ${ }^{17}$ It described one who was valued because he was of considerable benefit to his immediate society. ${ }^{18}$ At one time, this was the person who was heroic and successful in war, through his courage and physical abilities. ${ }^{19} \mathrm{He}$ was

${ }^{15}$ Cf. Dio, Or. 1, 16, 'For it is impossible that the olkaios and draobs durfp should repose greater confidence in any other being than in the $81 \mathrm{kalOl}$ and dplorol-the gods'; 32, 26, 'Among these over-lords, then, are included kings ... real guardians and $x p \eta \sigma \tau o l$ and 8 (kalol leaders of the people, gladly dispensing the dyade ...'

16 A.W.H. Adkins, Merit and Responsibility, A Study in Greek Values (Oxford, Clarendon Press 1960); Moral Values and Political Behaviour in Ancient Greece, From Homer to the End of the Fifth Century (London, Chatto and Windus 1972).

17 Adkins, Merit and Responsibility 30-1.

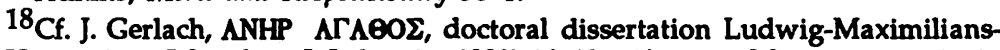
Universität, (München, J. Lehmaier 1932) 14, 'A raobs, vom Manne gesagt, ist in der Sprache der Inschriften nirgends weder an irgeneinem Ort noch zu irgendeiner Zeit ein individualethischer Begriff zur Bezeichnung immanenter Qualitäten, immer ist es vielmehr die Anerkennung des Staates oder einer Gemeinschaft für wertvolle Leistungen im Interesse der Gemeinschaft. Die Verdienste selbst mögen verschiedenster Art sein, immer ist es der Staat, der seinen Wohltäter durch Zuerkennung jener Bezeichnung ehrt. Wertendes Subjekt ist also die Gemeinschaft, bewertetes Objekt sind die Leistungen (einzelne oder mehrere), die Relation der Wertung ist ebenfalls die Gemeinschaft.'

${ }^{19} \mathrm{Cf}$. Liddell and Scott, sv dyatrs, where the meaning is given of 'brave' and 'valiant' 'since courage was attributed to chiefs and nobles'; also the sense of 'good' and 'capable' with reference to abilities. P.J. Rhodes, The Greek City States, A source book (London, Croom Helm 1986) 19, refers to Aristotle, Politics, IV.1297 B 16-22, The earliest constitution among the Greeks, after kingship, was that based on the warrior class, originally on the cavalry. 
considered dyatos because he could offer valuable protection to his family and dependants. Thus it was the dya 06 s man who, by virtue of his wealth, possessed armour and therefore could offer protection to his city. ayados thus became associated with the possession of wealth.

Later, the 'good man' was so-called because of his value to the city in the political realm. By virtue of his wealth he could afford the leisure to become involved in the political life of his city. dyatoss, in time, denoted a particular social class, namely the wealthy and ruling élite. We may note a similar distinction between a moral quality and a social class definition in our English words 'gentle' (gentleman), and 'noble' (nobleman, nobility.) ${ }^{20}$ dya $y$ s s particularly carried this sense of

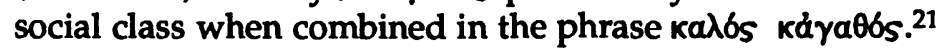

It is significant also for our present context that d ya $06 s$, as a social qualification, took precedence over some of the other moral values, such as, for example, sukaioovvm. Adkins writes,

To be agathos had always been more important than merely to be dikaios, and one's injustice did not traditionally-nor, it is clear, in the Athenian courts-impair one's arete. Again, to be agathos was to be a specimen of the human being at his best, making to society the contribution that society valued most; and the poorer citizens could not deny this, nor yet that they were not agathoi themselves. In

Strength and superiority in war used to depend on the cavalry, because a hoplite force is useless without an organised formation, and the ancients did not possess skill and organisation in these matters, so their strength was in their cavalry.'

${ }^{20} \mathrm{Cf}$. 'gentle' and 'noble' in the $O E D$.

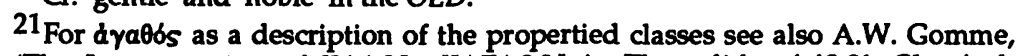

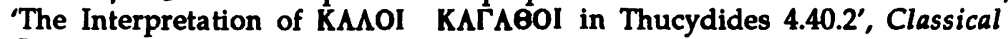
Quarterly 47, ns. 3 (1953) 65-8, who suggests that the term was very flattering, and normally appropriated to themselves by the upper classes - used by the well-to-do of themselves, and not necessarily used by others to describe the well-to-do. G.E.M. de Ste. Croix, 'Additional note on KALOS, KALOKAGATHIA', The Origins of the Peloponnesian War (London, 1972) 3716, draws similar conclusions. The original meaning of the phrase was of denoting excellence and distinction; he then points out, Then, in the late fifth century and the fourth, while the expression kalos kagathos continues to be used on occasion as a general term of commendation, two specialized uses become prominent: one essentially social-political, which develops first and can be seen clearly in Aristophanes and Thucydides, and the other primarily moral, emerging rather later, from Xenophon onwards-it is often thought to be largely a product of the Socratic circles.' 
accepting arete as more important than dikaiosune they were of course not letting their hearts run away with their heads, but treating the well-being of the city as more important than the injustice of an individual: a calculation of advantages. ${ }^{22}$

Thus, we see that in certain contexts the primary meaning of $₫ \gamma a \theta b s$ was a technical description for the wealthy upper classes, and, in these instances, it did not carry strong moral overtones. It would be incorrect to understand, in contrast to this, however, that $\delta$ kalos was a negative term. ${ }^{23}$ Frequently both terms would appear together as a laudatory description of some leading figure. We may accept, therefore, that these two nouns had different nuances in classical Greek, although both are commendable and desirable qualities. It remains to be shown that Hellenistic Greek retained these meanings, and consequently that it would have been reasonably used by someone with Paul's Hellenistic background.

During the Principate, the essential philosophy that value was to be given to those who offered the greatest benefits to their society was still highly conspicuous. ${ }^{24}$ Political security was more important than justice, and consequently political and military acumen, both requiring much capital outlay, were more highly prized qualities than 8 ika Wealth, family background and rank still attracted greater recognition than the quieter moral values. This can be clearly seen in the legal privileges which were accorded to those who were high-born and wealthy. ${ }^{26} \mathrm{~A}$ man could not easily bring a case against his social superior, except for certain crimes; those of high rank could not be executed for capital crimes; and if a rich man found a legal case going against him, he might draw

\footnotetext{
${ }^{22}$ Adkins, Moral Values 124; cf. also 126-7; Merit and Responsibility 70, 156.

${ }^{23}$ Contra for example Landau, op. cit. 32-34; and the slightly negative tone in Dodd, 75.

${ }^{24} \mathrm{Cf}$. Cremer, sv draobs, esp. 4, 7 where Rom 5:7 is alluded to.

${ }^{25}$ The dratoss would be expected to secure the advancement of his city at all costs, even that of Sukaiooinn.

${ }^{26} \mathrm{Cf}$. the thorough argument of P. Garnsey in Social Status and Legal Privilege in the Roman Empire (Oxford, Clarendon Press 1970). 'In law, as in other aspects of Roman society, the principal benefits and rewards were available to those groups most advantageously placed in the stratification system by reason of their greater property, power and prestige' idem. 280.
} 
the attention of the jury to some of the benefactions which he had given out of his 'generosity' to the city, and thus demonstrate his rectitude of character. ${ }^{27}$ Dio Chrysostom tries to counter this direct link between value and social status by suggesting that d $\rho \in T$ (excellence), as a moral quality, should be attributed to those who are virtuous in their actions, and not simply to those who are well-born. ${ }^{28}$

\section{Benefaction}

Once it is established that there can be this distinction between Sikalos and d'ya06s, it may already be seen how a man's debt to the dyatos is greater than to the merely sikalos. The former has been of some specific, probably financial and political, benefit to the immediate society and perhaps also to himself.

A deeply established social hierarchy, dominated by the wealthy and well-born, was continuously being reinforced during our period of the late Republic and early Empire. This was partly achieved by a convention of patronage which exploited the power inherent in giving gifts. ${ }^{29}$ The power of the wealthy was such that a high proportion of society was immediately dependent upon them. Influential men would have large staffs of slaves, whose whole livelihoods would be secured by their masters. A freedman would be under legal obligation and social pressure to continue to attend his master in business or politics long after being given liberty. Many freedmen might be dependent on the social élite for their daily finance. A young man starting out in public life would owe his initial reputation to a senior patron whose advice and support had been received.

${ }^{27}$ Cf. Plutarch, Moralia 817D; also S.C. Mott, 'The Power of Giving and Receiving: Reciprocity in Hellenistic Benevolence', in G.F. Hawthorne ed., Current Issues in Biblical and Patristic Interpretation (Grand Rapids, Eerdmans 1975) 69.

${ }^{28} \mathrm{Cf}$. Dio, Or. 15, 31, 'And so when a man is well-born in respect to virtue, it is right to call him "noble," even if no one knows his parents or his ancestors either.'

${ }^{29}$ Cf. S.C. Mott, op. cit. 60. H. Stephanus, Thesaurus Graecae Linguae I (Paris, 1831) sv dyad6s, gives the sense of 'euergeta, beneficus.' 
In Rome, social hierarchy was reinforced daily through the convention whereby socially inferior men would arrive each morning at the residences of their superiors for some form of dôle. This practice was part of the relationship of patronus and cliens; the attendance of the client was officium; and the dôle given to the dependant was called beneficium. ${ }^{30}$ The recipient of a beneficium was immediately under an obligation to his benefactor, and necessarily in his debt. The strength of the obligation was considerable, and social pressure to acknowledge and respond to the beneficium extreme. Social standing and reputation were linked to a complex network of relationships and obligations. To break an obligation was considered an offensive move which engendered enmity between the two parties. ${ }^{31}$

The advantage to the benefactor of this relationship was that it enhanced his own status and public recognition. For this reason, it is clear that benefaction was not normally a disinterested action, but a necessity by which the donor could maintain his security and public standing. ${ }^{32}$

\section{The Benefactor as the $d y a \theta \delta s$}

Godet questions why, if 'benefactor' is intended, Paul does not use the perfectly adequate Greek words of dyatomolós or $\epsilon \dot{\epsilon} \in \rho\} \overline{t \eta} s^{33}$ This may be simply explained by the natural reluctance to use the words patronus and cliens in direct address. Saller draws the conclusion,

Patently, the Romans applied the language of patronage to a range of relationships, with both humble dependants and their junior aristocratic colleagues labelled clientes: usage was more fluid than usually supposed, and the connotations of amicus, cliens and patronus were subtly and variously manipulated in different circumstances. It must be admitted, however, that the typical word for

${ }^{30}$ Seneca writes at length about this convention in his essays entitled $\mathrm{De}$ Beneficiis.

${ }^{31}$ Cf. A.R. Hands, Charities and Social Aid in Greece and Rome (London, Thames and Hudson 1968) 26.

${ }^{32}$ P. Marshall, Enmity in Corinth, Social Conventions in Paul's relations with the Corinthians (Tübingen, J.C.B. Mohr [Paul Siebeck] 1987) 2.

${ }^{33}$ Godet, 326. Cf. also Meyer, 234. 
a junior aristocratic associate and others further down the social ladder was amicus. ${ }^{34}$

In some instances, where social comparisons of status were less obvious, the term would happily be used. We may note the parallel usage in Dio's Orationes of the nouns dyatos

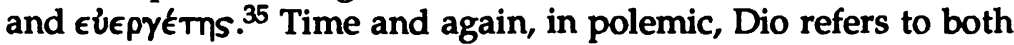
the benefactors of the city and the good men of society in the same breath, clearly as the same group of people. In one famous oration against the citizens of Rhodes, we find a number of such parallels,

'It is in regard to these matters, men of Rhodes, that I ask you to believe that the situation here among you is very bad and unworthy of your state, your treatment, I mean, of your eúepyétal and of the

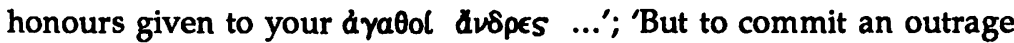

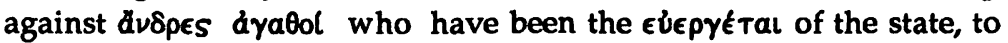
annul the honours given them and to blot out their remembrance, I

${ }^{34}$ R.P. Saller, 'Patronage and Friendship', in A. Wallace-Hadrill ed., Patronage in Ancient Society (London, Routledge 1989) 57; cf. also Saller, Personal Patronage under the Early Empire (Cambridge, CUP 1982) 9, 'The reason for the infrequent appearance of patronus and cliens in literature lies in the social inferiority and degradation implied by the words.'

${ }^{35} \mathrm{Cf}$. Dio, Or. 46, 2-3, Now with reference to my father, there is no need for me to tell whether he was an dyaobs, for you are always singing his praises, both collectively and individually, whenever you refer to him, as being no ordinary citizen ... Again, no one could say of my grandfather either that he disgraced the city or that he spent nothing on it out of his own means. For he spent on public benefactions all that he had from his father and his grandfather, so that he had nothing left at all.' Cf. also Plutarch, Moralia -218A, where an dya日bs king is described as one who is benefactor to his friends; and 851D, 'Laches, son of Demochares, of Leuconoë, asks from the senate and people of the Athenians for Demochares, son of Laches, of Leuconoë, a grant of a bronze statue in the market-place, and maintenance in the Prytaneum for him and the eldest of his descendants in perpetuity, and the privilege of a front seat at all

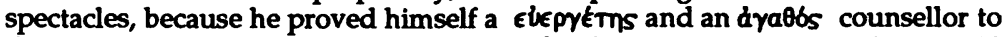
the people of the Athenians and benefited the people ...' Philippi, 240, includes the citation from Xenophon, Cyrop. iii.3.4, KOpov duaka入oovTes Tov

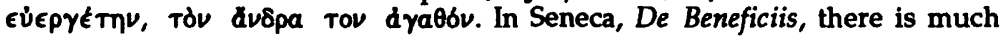
evidence to show a connection between the 'good man' and the one who is benefactor. Cf. II.17.7, 'The best man is he who gives readily, never demands any return, rejoices if a return is made, who in all sincerity forgets what he has bestowed, and accepts a return in the spirit of one accepting a benefit.' VII.17.2, 'To a good man I shall hand back his benefit, to a bad one I shall fling it back; to the former, because I am indebted to him, to the latter, in order that I may no longer be indebted to him.' VII.19.3, 'to a good man I shall make return when it is convenient; to a bad man, when he asks for it.' 
for my part do not see how that could be otherwise termed'; The one

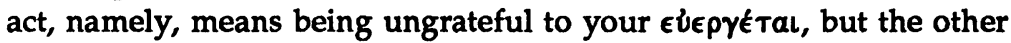
means insulting them; the one is a case of not honouring the $2 \nu \delta \rho \in S$ dyatol, the other, of dishonouring them'; 'How very much worse it is to rob a rabol of honours bestowed than to rob anybody else, and to

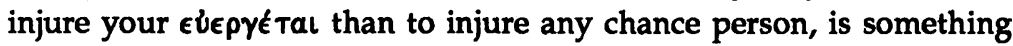
that nobody fails to see. ${ }^{36}$

We may also turn to epigraphic evidence which usefully shows this direct link between the benefactor and the good man. With regard to a benefactor, the Athenians determined,

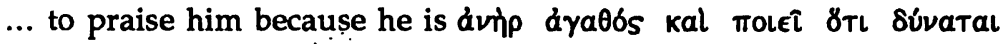
ara $\gamma \partial \partial \nu$ for the people of Athens ... it is resolved that Menelaos be considered a benefactor. ${ }^{37}$

There, is therefore a definite connection in Hellenistic Greek between the $d \gamma \alpha \theta b s$ and the benefactor. It is a connection that we see both in literary and epigraphic evidence.

\section{Conclusion}

If we are correct, with Cranfield and others, in drawing a link between dyatos and 'the benefactor' in Romans 5:7, this may explain the gradation in $7 \mathrm{~b}$, thus answering the questions raised by Godet above. ${ }^{38}$ It may then be asked if Paul elsewhere talks in these secular terms. We have noted already the contrasting instance in Romans 7, where Paul is clearly using a ya06s in its moral sense instead. As in Romans 5:7, Winter argues that the

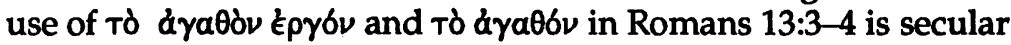
benefaction terminology. A similar usage may be seen in the

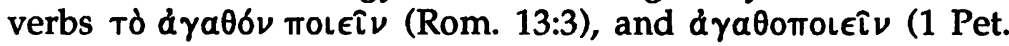

${ }^{36}$ Dio, Or. 31, 8; 31, 14; 31, 27; 31, 65.

${ }^{37}$ W. Dittenberger, Sylloge Inscriptionum Graecarum I-IV (Leipzig, S. Hirzel 1918-24) 174. Cf. also Sammlung der griechischen Dialekt-Inschriften, ed. H. Collitz et al. (Göttingen, 1884-1915) 5366, 5464, 5698 and SIG 127, 167, (all cited by Winter, op. cit. 100, n. 32). From the first century and early second century period we may add SIG 704, 800, 805, 1019. Gerlach, op. cit. 7-14, gives further epigraphic evidence for the use of the term anjp a yaobs.

${ }^{38}$ See p. 133. 
2:14). ${ }^{39}$ A further possible parallel has been suggested in Galatians 6:10.40

Romans 5:7 has proven problematic to a number of commentators, because the adjectives 'good' and 'just' in the twentieth century both carry moral connotations. We have seen, however, that a frequent meaning of $\alpha \gamma a \theta \delta s$ in first century cultural usage would have been to the social élite; and a widely

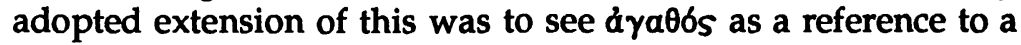
benefactor of a city or individual.

If we take 'benefactor' as the implied meaning in Romans 5:7, it may then clearly be seen why, 'very rarely will anyone die for a righteous man, though for a good man someone might possibly dare to die.' The obligations which were owed to one's benefactor were socially binding, and it would not have been unthinkable for a man to lay down his life for such an honourable person. There is a similar resonance in Dio;

for, whereas in the cause of justice and virtue and ancestral rights and laws, a noble soul, one that does not cling to life, will, if need be, suffer, and even die for a good king; yet if a man hangs himself for a chorusgirl, a low-born outcast, not fit to live, what depths of disgrace does that betoken! ${ }^{41}$

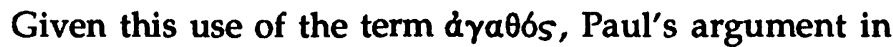
Romans 5:6-8 comes very sharply into focus. While it is almost

${ }^{39}$ Winter, op. cit. 92-3, against Cranfield, $A$ Critical and Exegetical Commentary on the Epistle of Paul to the Romans II (Edinburgh, T. \& T. Clark 1979) 664 n. 5. Cranfield suggests that, in Romans 13:3, the sense of dra0bs is naturally to be taken as moral.

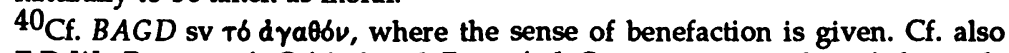
E.D.W. Burton, A Critical and Exegetical Commentary on the epistle to the Galatians (Edinburgh, T. \& T. Clark 1921) 346, 'The expression is not quite identical with To $k a \lambda b v$, v. 9, signifying, rather, what is beneficial to another than what is morally right.' H.A.W. Meyer, Critical and Exegetical Commentary on the New Testament VII The Epistle to the Galatians (ET; Edinburgh, T. \& T. Clark 1884) 335f., on the contrary does not see this as a reference to beneficence, although he does list a number of commentators who do adopt this stance.

${ }^{41}$ Or. 32, 50. M. Hengel, The Atonement, The Origins of the Doctrine in the New Testament (ET; Philadelphia, Fortress Press 1981) 9-14, gives a discussion of instances in Greek literature of people prepared to die on behalf of their native city, friends or family. However, he does not draw the obvious Pauline parallel of human self-sacrifice in Romans 5:7. 
inconceivable that someone would give up their life merely for an upright citizen, it is not unthinkable in the first century that someone-because of the ties of patronage-would give up their life for their benefactor, $\delta$ dyatoss. Yet Christ gave up his life for us-when we were yet sinners without any claim on him. ${ }^{42}$ It has been shown that support for this interpretation is by no means lacking. Indeed a survey of the commentators would suggest that it received widespread acceptance during the nineteenth century. More recently the interpretation has increased once again in favour, although it has not been defended with the same conviction which it once enjoyed. The present discussion, whilst bringing to light some of the older support, also seeks to provide additional evidence which firmly endorses the revived viewpoint. ${ }^{43}$

${ }^{42}$ Cranfield, 264, notes that 'benefactor' and àya0bs as references to God are not uncommon descriptions in the Old Testament, and most especially in the Psalms. It is clear that Jesus' death, however, is here being treated by Paul in dialectical contrast to the benefaction concept. It is the one, elsewhere termed benefactor, who is dying for his clients.

${ }^{43}$ I should like to acknowledge the helpful advice and valuable insight of Miss J. Reynolds and Drs B.W. Winter, and E. Bammel in the writing of this paper. 